\title{
Quantitative interrelations of Lewis antigens in normal mucosa and transitional cell bladder carcinomas
}

\author{
C Limas
}

Abstract

The factors regulating the expression of the Lewis blood group related antigens in tissues have yet to be clarified. In an attempt to resolve some of the existing controversies the quantitative interrelationship of the $L e^{a}, L e^{b}, X$ and $Y$ antigens in normal urothelium and transitional cell carcinomas (TCC) was studied using biopsy specimens derived from 22 patients whose $A B O$ and Lewis red blood cell phenotype was known. A quantitative scale was devised to encompass both the extent and intensity of the immunohistochemical reactivity in one numerical value (score). The expression of these four antigens in the normal urothelium followed a characteristic pattern that is related to but not identical with the red blood cell phenotype. An excess of $L e^{b}$ and $Y$ in the urothelium correlated with the $\mathrm{Le}^{\mathrm{a}-\mathrm{b}+}$ red blood cell phenotype, while a relative increase in Le and $X$ (at the expense of $L^{b}$ and $Y$ ) was associated with the $\mathrm{Le}^{\mathrm{a}+\mathrm{b}-}$ red blood cell phenotype. This pattern can be accounted for by the combined effects of differential gene expression and substrate availability.

The quantitative comparison of the antigenic make-up of TCCs with the corresponding normal tissue phenotype shows consistent trends, suggesting that the changes associated with neoplasia derive primarily from the suppression of specific gene products and, secondarily, from altered competitive substrate utilisation.

Several issues concerning the function and modulation of blood group substances in normal and disease states remain unresolved. Using immunochemical and immunohistochemical methods, significant changes in the major antigenic determinants $A, B$, and $H$ have been identified in neoplasia. In particular, it has been suggested that the expression of BG antigens is depressed in transitional cell carcinomas with unfavourable clinical course, ${ }^{1-3}$ although the clinical relevance of this observation remains uncertain. ${ }^{4}$

Closely related to the $A, B$, and $H$ antigens are the Lewis antigens ( $\mathrm{Le}^{\mathrm{a}}, \mathrm{Le}^{\mathrm{b}}, \mathrm{X}$ and $\mathrm{Y}$ ) which are under the control of the Le gene and its interaction with the products of the Se and
H genes. ${ }^{56}$ The tissue Lewis antigens have also been reported to change in association with neoplastic growth, ${ }^{7-12}$ but the interpretation of these findings is hampered by the complexity of the genetic control of the antigens, their variable expression depending on tissue type and cellular differentiation, and the lack of standardised, quantitative methodology. The initial observations using the red cell adherence test ${ }^{7}$ were subsequently confirmed with monoclonal antibodies in immunohistochemical assays. ${ }^{12} 13$ These studies showed that the expression of $\mathrm{Le}^{\mathrm{a}}$ and $\mathrm{Le}^{\mathrm{b}}$ antigens in normal urothelium does not conform to the red blood cell phenotype, a finding recently confirmed by enzymatic assays. ${ }^{14}$

This study was undertaken to find out about the expression of the $\mathrm{Le}^{\mathrm{a}}, \mathrm{Le}^{\mathrm{b}}, \mathrm{X}$ and $\mathrm{Y}$ antigens in the urothelium and the changes occurring in neoplasia. We therefore analysed the quantitative interrelations of these four antigens in tissue sections with reference to the red blood cell phenotype. The results suggest that tissue antigen expression is related to the Lewis red blood cell phenotype and that the changes in neoplasia are best explained on the basis of altered gene suppression and substrate availability.

\section{Methods}

Tissues were taken from men aged 44 to 75 years, according to the following criteria: (1) the patients' red blood cells had been typed for $\mathrm{ABO}$ and $\mathrm{Le}^{\mathrm{a}}, \mathrm{Le}^{\mathrm{b}}$ in our laboratory; (2) biopsy specimens containing morphologically normal mucosa were available, and at least one of these was obtained simultaneously with those containing neoplastic urothelium; (3) there had been no treatment for urothelial cancer before the biopsy specimens had been taken; (4) all morphologically normal mucosae had been tested for $\mathrm{A}, \mathrm{B}, \mathrm{H}$ antigens and displayed the expected reactivity; (5) all TCCs had been tested for the expected $\mathrm{A}, \mathrm{B}, \mathrm{H}$ antigens and were negative.

Criterion 4 was applied to ascertain that the morphologically normal transitional epithelium had not undergone antigenic changes even though it had been taken from patients with neoplasia elsewhere in the bladder.

Criterion 5 was applied to restrict the phenotypic variability of TCCs which could complicate the interpretation of the Lewis reactivity by introducing secondary pheno- 
Figure 1 Representative grade 3 transitional cell carcinoma (Haematoxylin and eosin).

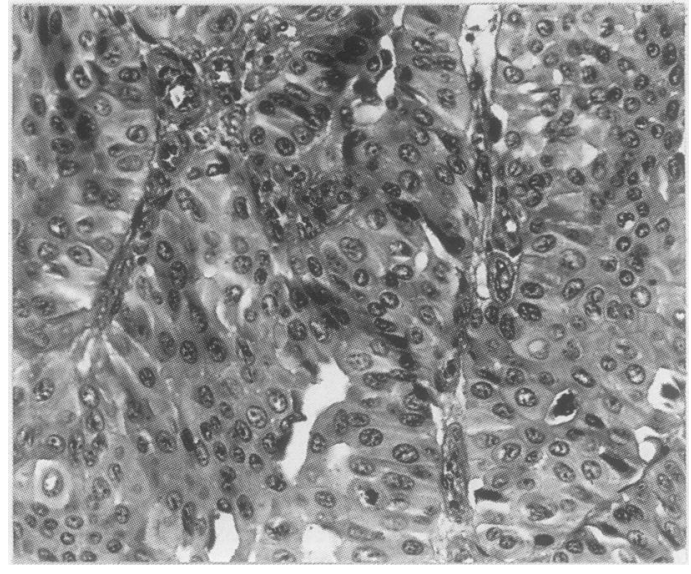

mena-for example, complex antigenic interactions, substrate availability, etc.

All TCCs examined were grade 3 (fig 1); 10 had muscle invasion, six superficial invasion, and six were non-invasive in the biopsy specimens studied.

The prevalence of the Lewis phenotypes in the patient population of the Minneapolis VA Medical Center is similar to that of caucasians: $\mathrm{Le}^{\mathrm{a}-\mathrm{b}+} 74 \%, \mathrm{Le}^{\mathrm{a}+\mathrm{b}-} 18 \%$, and $\mathrm{Le}^{\mathrm{a}-\mathrm{b}-} 8 \%$ (based on 550 patients tested by us). An effort was made to include in this study an adequate number of patients from each of the three Lewis phenotypes, $\mathrm{Le}^{\mathrm{a}^{-\mathrm{b}+}}, \mathrm{Le}^{\mathrm{a+b}-}, \mathrm{Le}^{\mathrm{a}-\mathrm{b}-}$. Thus, 22 patients were selected: eight $\mathrm{Le}^{\mathrm{a}-\mathrm{b}+}$, nine $\mathrm{Le}^{\mathrm{a}+\mathrm{b}-}$, and five $\mathrm{Le}^{\mathrm{a}-\mathrm{b}-}$. Tissues were processed to paraffin wax in 22 and were also fresh frozen in 13. On average, four tissue blocks per patient were processed for immunohistochemistry, and duplicate sections from each block were assayed for each antigen. A series of preliminary experiments was performed using control tissues and variable dilutions of the antibodies to establish a reproducible quantitative scale of scores.

Anti-A and anti-B sera for red blood cell typing were purchased from Accugenics, Costa Mesa, California and Cooper Biomedical Inc., Malvern, Philadelphia. Monoclonal antibodies to $A, B$, and $\mathrm{H}$ antigens were obtained from Dako, Carpinteria, California. Monoclonal anti-Le ${ }^{\mathrm{a}},-\mathrm{Le}^{\mathrm{b}}, \mathrm{X}$ and $\mathrm{Y}$ antibodies were developed against tissue immunogens (table 1) and were obtained from Cambridge Research Laboratories, Cambridge, Massachusetts. These antibodies have been evaluated in detail and used for the detection of Lewis antigens by previous investigators. ${ }^{15-18}$

The immunohistochemistry was performed as previously reported. ${ }^{12}$ Briefly, serial sections were cut at $6 \mu \mathrm{m}$ thickness and dewaxed, (frozen sections were fixed in $10 \%$ neutral buffered formalin), washed in TRIS- $\mathrm{HCl}$ ( $\mathrm{pH}$ 7.6) containing $0 \cdot 15 \mathrm{M} \mathrm{NaCl}$, and incubated

Table 1 Monoclonal antibodies use for detecting Lewis antigens in tissues

\begin{tabular}{llll|}
\hline $\begin{array}{l}\text { Immunogen } \\
\text { cultured cell line }\end{array}$ & Clone & Immunoglobulin & $\begin{array}{l}\text { Antigen } \\
\text { specificity }\end{array}$ \\
\hline SK-CO-10 colon cancer & T174 & IgG & $\mathrm{Le}^{2}$ (type 1 chain) \\
SK-CO-10 colon cancer & T218 & IgM & Le (type 1 chain) \\
Fresh human placenta & P12 & IgM & X (type 2 chain) \\
SK-LU-3 lung cancer & F3 & IgM & Y (type 2 chain) \\
\hline
\end{tabular}

with blocking serum (goat or horse). Duplicate sections were incubated with each monoclonal antibody at a predetermined optimal dilution. They were then washed in buffered saline and incubated with a biotinylated anti-mouse IgG or IgM for one hour. After washing they were incubated with Vectastain (Vector Laboratories, Inc., Burlingame, California) for one hour, washed again, and finally the colour reaction was obtained using diaminobenzidine and $\mathrm{H}_{2} \mathrm{O}_{2}$. All reactions were performed at room temperature in a moisture chamber. Tissues of known reactivity were processed in parallel with the test tissues and served as controls for reproducibility of quantitation. Sections incubated in the absence of primary antibody were used to evaluate non-specific staining. The results were recorded without knowledge of the red blood cell phenotype and a score was calculated for each tissue block and each antigen according to the following quantitative scale (table 2).

This scale expresses the relative concentration of each antigen within a given tissue sample as a single numerical value. The concentration of antigen in the tissue depends on both the number of positive cells and the amount of antigen per cell. The staining pattern-that is, the topographical distribution of positive cells-does not influence the score. Combinations of extent and intensity that were not encountered or not reliably reproduced were not used in constructing this scale. Errors due to artefactual uneven staining were eliminated because all tests were performed on at least two sections from each block and were repeated whenever the scores showed discrepancies. The individual scores were used to calculate the mean and standard deviation for each antigen within each phenotypic group.

\section{Results}

All four antigens ( $\mathrm{Le}^{\mathrm{a}}, \mathrm{Le}^{\mathrm{b}}, \mathrm{X}$ and $\mathrm{Y}$ ) were expressed in the normal urothelium but, as shown in table 3 and fig 2, significant quantitative differences existed which could be related to the red blood cell Lewis phenotype. In general, the $\mathrm{Le}^{\mathrm{a}-\mathrm{b}+}$ phenotype was associated with higher $\mathrm{Le}^{\mathrm{b}}$ and $\mathrm{Y}$ and lower $\mathrm{Le}^{\mathrm{a}}$ and $\mathrm{X}$ scores compared with the $\mathrm{Le}^{\mathrm{a}+\mathrm{b}-}$ phenotype. A reciprocal relation was obvious between $\mathrm{Le}^{\mathrm{a}}$ and $\mathrm{Le}^{\mathrm{b}}$ (figs 3 and 4 ). The $\mathrm{Le}^{\mathrm{a}-\mathrm{b}-}$ phenotype had the lowest scores for all except the $\mathrm{X}$ antigen. The scatter of the scores for each antigen as shown in fig 2 indicated that, with the exception of three $\mathrm{Le}^{\mathrm{a}-\mathrm{b}-}$ subjects, all normal mucosae reacted with a

Table 2 Quantitative scale for tissue Lewis antigens

\begin{tabular}{lll}
\hline Score & Extent & Intensity \\
\hline 100 & All cells & strong \\
75 & Over $50 \%$ & strong \\
50 & Over $50 \%$ or & moderate \\
& $30-50 \%$ & strong \\
25 & Over $50 \%$ or & weak \\
& $30-50 \%$ or & moderate \\
& $10-30 \%$ & strong \\
12.5 & $30-50 \%$ or & weak \\
& $10-30 \%$ & moderate \\
6.25 & Less than $10 \%$ & moderate or strong \\
\hline
\end{tabular}


Figure 2 Distribution of the scores for the $L e^{a}, L e^{b}$, $X$ and $Y$ antigens in normal and neoplastic urothelium and its relation to the red blood cell phenotype.
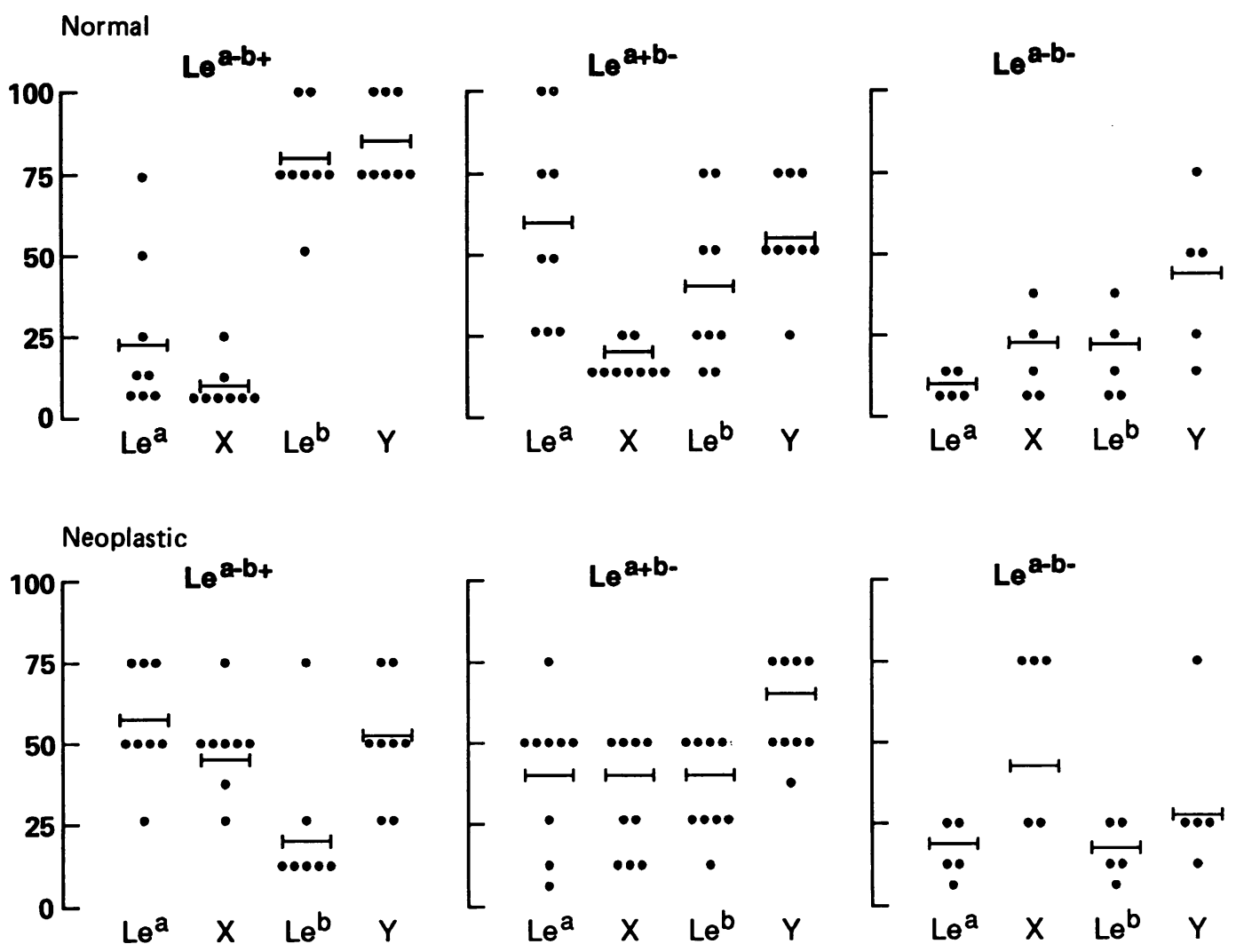

score of 25 or higher for at least one of the two Le antigens, while the score for $\mathrm{X}$ was consistently 25 or lower, with the exception of one $\mathrm{Le}^{\mathrm{a}-\mathrm{b}-}$ patient. The scores for $\mathrm{Le}^{\mathrm{b}}$ showed considerable variability among phenotypically $\mathrm{Le}^{\mathrm{a}+\mathrm{b}-}$ patients. The scores for $\mathrm{Y}$ were 25 or greater for all except one $\mathrm{Le}^{\mathrm{a}-\mathrm{b}-}$ patient.

Cellular differentiation had some effect on the intramucosal distribution of the staining, particularly for the $\mathrm{X}$ and $\mathrm{Y}$ antigens. The $\mathrm{X}$ antigen was identified in the superficial (luminal) cell layer of all patients and only rarely was detectable in additional layers (fig 5) In contrast, the $\mathrm{Y}$ antigen showed a predilection for the deeper layers (fig 6). It was also noted that in phenotypically $\mathrm{Le}^{\mathrm{a}-\mathrm{b}+}$ patients the $\mathrm{Le}^{\mathrm{a}}$ antigen localised predominantly in the luminal layer (fig 4A). In most cases the staining was intracytoplasmic in granules and vesicles and only rarely was it confined to the cell surface.

The ABO phenotype had no apparent effect on the urothelial reactions for any of the four antigens but strongly influenced the detectability of the $\mathrm{Y}$ determinant in endothelial cells. The results shown in table 4 clearly show that the $\mathrm{Y}$ antigen is strongly expressed in the

Table 3 Quantitative expression (mean (SEM)) of Le $e^{a}, L e^{b}, X$ and $Y$ antigens in normal urothelium: association with red blood cell phenotype

\begin{tabular}{llll}
\hline \multirow{4}{*}{ Antigen } & \multicolumn{3}{l}{ Red blood cell phenotype } \\
\cline { 2 - 4 } & $L e^{a-b+}(n=8)$ & $L e^{a+b-}(n=9)$ & $L e^{a-b-}(n=5)$ \\
\hline Le $^{a}$ & $24(9)$ & $58(10)$ & $9(2)$ \\
Le & $9(2)$ & $15(2)$ & $15(4)$ \\
$\mathrm{Le}^{\mathrm{b}}$ & $78(6)$ & $39(8)$ & $15(4)$ \\
Sum of scores & $84(5)$ & $56(6)$ & $42(11)$ \\
\hline
\end{tabular}

endothelium of all BGO patients but is weak or undetectable in patients with $A$ or B blood groups. The anti-Le $e^{a}$ anti-Le ${ }^{b}$ and anti-X antibodies did not react with the endothelial cells in the tissue sections.

The reactivity of TCCs for the $\mathrm{Le}^{\mathrm{a}}, \mathrm{Le}^{\mathrm{b}}, \mathrm{X}$ and $\mathrm{Y}$ antigens was evaluated in conjunction with the reactivity of normal urothelium. As shown in table 5 and fig 2 , the major findings in TCCs were: (a) a shift from $\mathrm{Le}^{\mathrm{b}}$ to $\mathrm{Le}^{\mathrm{a}}$ and from $\mathrm{Y}$ to $\mathrm{X}$ in patients with $\mathrm{Le}^{\mathrm{a}-\mathrm{b}+}$ phenotype; (b) a reciprocal change between $L^{a}$ and $X$ in patients with $\mathrm{Le}^{\mathrm{a}+\mathrm{b}-}$ phenotype; (c) an increase in $\mathrm{X}$ in all phenotypes; and (d) a decrease of products derived from type 1 chain precursors. Table 4 shows that the sum of the scores was quite close in normal urothelium and TCCs despite the very noticeable differences when comparing the scores of single antigens. This was due to the reciprocal nature of the changes which was very striking for some antigens-for example, between $\mathrm{Le}^{\mathrm{a}}$ and $\mathrm{X}$ in $\mathrm{Le}^{\mathrm{a}+\mathrm{b}-}$ patients and the sums of $\mathrm{Le}^{\mathrm{a}}+\mathrm{X}$ versus $\mathrm{Le}^{\mathrm{b}}+\mathrm{Y}$ in $\mathrm{Le}^{\mathrm{a}-\mathrm{b}+}$ patients. As in normal cells, the staining was intracytoplasmic and was only rarely confined to the cell surface. Within each TCC the variability of staining was greater than in normal urothelium.

There was no correlation between the detectability of A, B, H and that of the Lewis antigens. All the TCCs in this study were selected because they were $A, B, H$ negative.

\section{Discussion}

Evidence obtained for a variety of tissues suggests that neoplastic transformation is associated with disturbances in several 

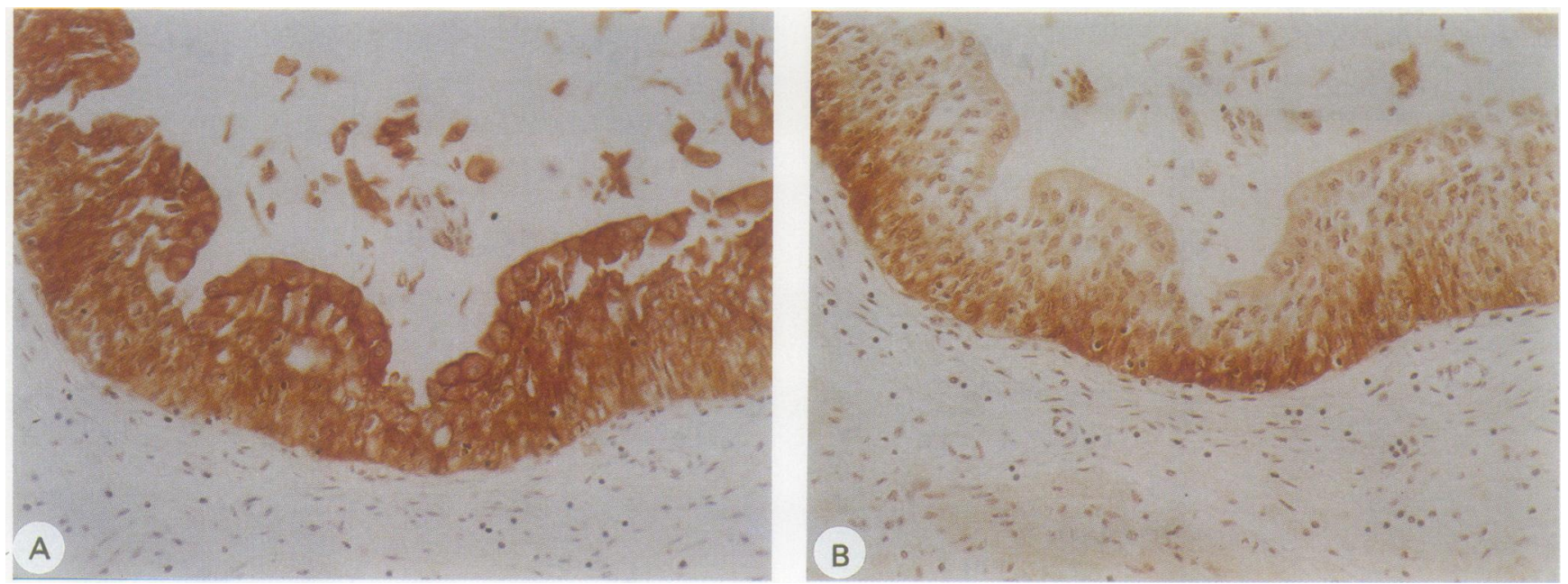

Figure 3 Normal bladder mucosa from a patient with Le ${ }^{a+b-}$ red blood cell phenotype reacted with: (a) anti-Le (score 100) and (B) anti-Le (score 25). Note that the anti-Le $e^{b}$ reacts preferentially with the deeper layers. The endothelium is negative for both Le $e^{a}$ and Le $e^{b}$.

antigenic determinants including those of the $\mathrm{ABO}$ and Lewis blood group systems. The interpretation of the changes involving the Lewis antigens has met with difficulties because of the complexity of their biosynthetic pathways which require the concerted action of the products of several genes.

Figure 6 is a simplified outline of the biosynthesis of the Lewis antigens ${ }^{56}$ which served as a conceptual framework for the interpretation of our results. According to this scheme, $\mathrm{Le}^{\mathrm{a}}$ synthesis requires the action of a fucosyltransferase (encoded by the Le gene) on a type 1 precursor. The formation of $\mathrm{X}$ could be catalysed either by the same enzyme (same Le gene) acting on a type 2 precursor or by a different fucosyltransferase (X gene) whose action is limited to type 2 substrates. The formation of $\mathrm{Le}^{\mathrm{b}}$ requires the consecutive action of two fucosyltransferases; the first, encoded by the Se gene, catalyses the synthesis of $\mathrm{H}$-type 1 , while the second, encoded by the Le gene, fucosylates the $\mathrm{H}$-type 1 into $\mathrm{Le}^{\mathrm{b}}$. If, instead of type 1 , a type 2 precursor chain is utilised as acceptor, $\mathrm{H}$-type 2 is formed and is further fucosylated by the Le or X enzyme into
Y. H-type 2 can be formed independently of the Se gene and then fucosylated into $Y$ by the $\mathrm{X}$ enzyme.

Although these biosynthetic pathways explain many observations and experimental data, it has recently been recognised that there is tissue dependent variability in the expression of the Lewis genes. ${ }^{12} 1419$ The red blood cell Lewis phenotype depends on the adsorption of serum glycoproteins the tissue origin(s) of which remain unknown. ${ }^{20}$ With rare exceptions, ${ }^{21}$ subjects with the $\mathrm{Le}^{\mathrm{a}-\mathrm{b}+}$ red blood cell phenotype secrete blood group $\mathrm{A}, \mathrm{B}$, or $\mathrm{H}$ substances in their saliva, a trait determined by the Se gene. Those with the $\mathrm{Le}^{\mathrm{a}+\mathrm{b}-}$ red blood cell phenotype do not have this characteristic as they are homozygous for the recessive gene se (non-secretors). The red blood cell phenotype $\mathrm{Le}^{\mathrm{a}-\mathrm{b}-}$ denotes that the person lacks the Le gene but may or may not retain the Se gene. Discrepancies have been found between the red blood cell Lewis phenotype and the detectability of $\mathrm{Le}^{\mathrm{a} / \mathrm{b}}$ in the normal urothelium ${ }^{712}$ and enzymatic studies have suggested that the Le gene is expressed in the urothelium regardless of the red blood cell phenotype. ${ }^{14}$
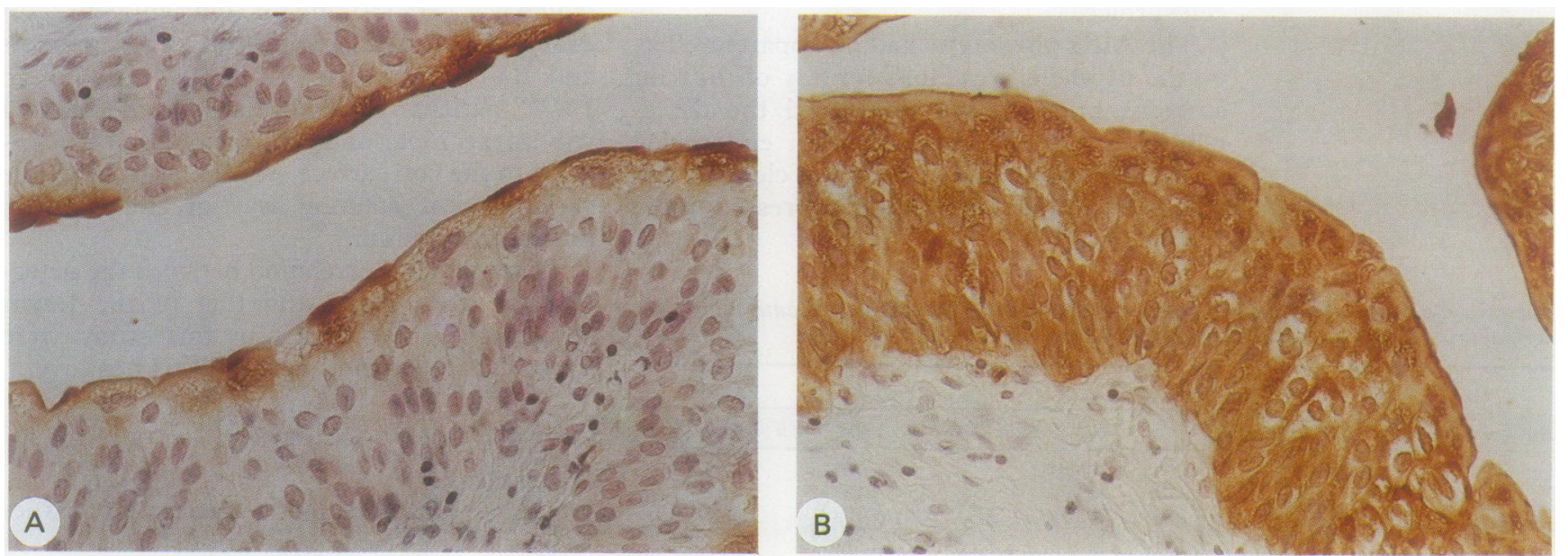

Figure 4 Normal bladder mucosa from a patient with L $e^{a-b+}$ red blood cell phenotype reacted with: $(A)$ anti-Le $e^{a}$ (score 12.5) and (B) anti-Le $e^{b}$ (score 75). Note the staining of vesicular intracytoplasmic structures and the absence of endothelial reactivity with either antigen. 


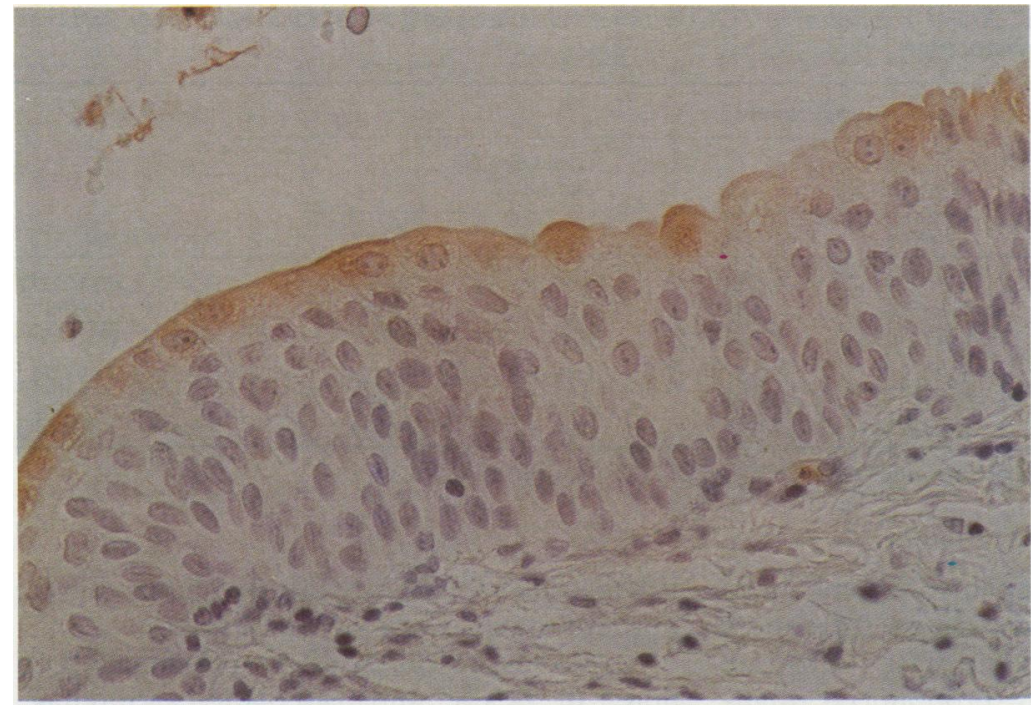

Figure 5 Normal bladder mucosa with anti-X. The staining is confined to the luminal cell layer (score 6.25). There is no endothelial reactivity.

We have found that the quantitative differences in the expression of the four antigens $\mathrm{Le}^{\mathrm{a}}$, $\mathrm{Le}^{\mathrm{b}}, \mathrm{X}$, and $\mathrm{Y}$ in the normal urothelium can be related to the red blood cell phenotype. In accordance with fig 6 and the results shown in table 2, subjects apparently lacking the Se gene utilise the precursor substrates predominantly for the synthesis of $\mathrm{Le}^{\mathrm{a}}$ and $\mathrm{X}$ while the strong expression of Se shifts the reaction toward the synthesis of $\mathrm{H}$ and, consequently, $\mathrm{Le}^{\mathrm{b}}$ and $\mathrm{Y}$ are formed at the expense of $\mathrm{Le}^{\mathrm{a}}$ and $\mathrm{X}$. The reciprocal relationship between $\mathrm{Le}^{\mathrm{a}}$ and $\mathrm{Le}^{\mathrm{b}}$ is particularly striking and strongly supports the concept of competitive utilisation of common type 1 precursor substrates. The reciprocal relationship between $\mathrm{X}$ and $\mathrm{Y}$ is not as strong, probably because of the existence of alternative pathways not under Se/Le control (fig 6C). The results shown in table 2 also suggest that the alternative pathways utilising type 2 precursors are operable in the urothelium of subjects with Le negative $\left(\mathrm{Le}^{\mathrm{a}-\mathrm{b}-}\right)$ red blood cell phenotype. Such people, although heterogeneous in the expression of Lewis determinants in the urothelium, have a much lower score of tissue $\mathrm{Le}^{\mathrm{a}}$ and $\mathrm{Le}^{\mathrm{b}}$ antigens which can be associated with an apparent
Table 4 Expression of $Y$ antigen in endothelium: correlation with $A B O$ blood group

\begin{tabular}{llll}
\hline & \multicolumn{3}{c}{ Score of reactions with anti-Y } \\
\cline { 2 - 4 } Blood group & $75-100$ & $12 \cdot 5-25$ & $<12 \cdot 5$ \\
\hline A & 0 & 2 & 7 \\
B & 0 & 0 & 2 \\
O & 11 & 0 & 0 \\
\hline
\end{tabular}

absence or undetectable titres of these antigens from the serum and consequently from the red blood cells.

The activities of the specific fucosyltransferases encoded by the Se, $\mathrm{H}$, Le and $\mathrm{X}$ genes have been measured in normal urothelium and found to be similar in secretors and nonsecretors as well as in Lewis positive and negative persons when the same exogenous acceptor substrates were used in the assay. ${ }^{14}$ The level of antigen expression, however, is the end result of the concerted interaction of several cellular factors not accounted for in the in vitro assays. For example, the addition of fixed amounts of exogenous substrates in these assays may mask differences in endogenous substrate accessibility to competing biosynthetic enzymes.

In addition to the urothelium, an excess of $\mathrm{Le}^{\mathrm{b}}$ in secretors and $\mathrm{Le}^{\mathrm{a}}$ in non-secretors has been found in the gastric surface epithelium. ${ }^{22}$

The interpretation of the changes associated with neoplastic transformation is more complex. Some of this complexity can be removed by comparing the expression of each antigen in tumours and their normal counterparts within the same phenotypic group. We have previously reported a relative decline of $\mathrm{Le}^{\mathrm{b}}$ in TCCs from $\mathrm{Le}^{\mathrm{a}-\mathrm{b}+}$ subjects and a relative depression of $\mathrm{Le}^{\mathrm{a}}$ in TCCs from $\mathrm{Le}^{\mathrm{a}+\mathrm{b}-}$ patients. ${ }^{7}$ Other investigators have noted abnormal expression of Lewis antigen $\mathrm{s}^{810}$ but the lack of a consistent pattern has made it difficult to form a coherent idea. In this study, we expressed the morphological observations quantitatively so that the deviations of each antigen from normal could be measured and related to changes simultaneously affecting the other antigens. The reduction of the difucosylated substances $\mathrm{Le}^{\mathrm{b}}$ and $\mathrm{Y}$ in TCCs of phenotypically $\mathrm{Le}^{\mathrm{a}-\mathrm{b}+}$ subjects can best be accounted for by reduced expression of the $\mathrm{Se} /$
Figure 6 Staining for $Y$ of normal bladder mucosa from: $(A)$ a patient with $B G O, L e^{a+b-}$ red blood cell phenotype (score 50) and $(B)$ a patient with $B G A, L e^{a-b+}$ red blood cell phenotype (score 100). Note the endothelial reactions.

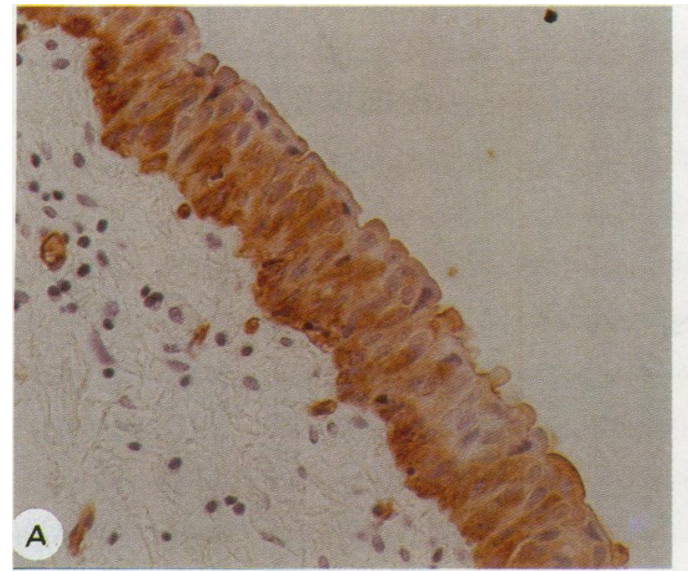


Table 5 Expression of $L e^{a}, L e^{b}, X$ and $Y$ antigens in TCCs with reference to normal transitional epithelium, and red blood cell phenotype, precursor chain type

\begin{tabular}{|c|c|c|c|c|c|c|}
\hline \multirow{3}{*}{$\begin{array}{l}\text { Patients' } \\
\text { red blood } \\
\text { cell } \\
\text { phenotype }\end{array}$} & \multirow{3}{*}{$\begin{array}{l}\text { Chain } \\
\text { type }\end{array}$} & \multicolumn{4}{|c|}{ Tissue (normal/tumour) } & \multirow[b]{3}{*}{ Sum of scores } \\
\hline & & \multicolumn{2}{|c|}{ Gene Le (X) } & \multicolumn{2}{|c|}{$\begin{array}{l}\text { Genes } S_{e}(H) \\
\text { and Le }(X)\end{array}$} & \\
\hline & & Antigen & Score & Antigen & Score & \\
\hline $\begin{array}{l}\mathbf{L e}^{a-b+} \\
(n=8)\end{array}$ & $\begin{array}{l}1 \\
2\end{array}$ & $\begin{array}{l}\operatorname{Le}^{a} \\
\mathbf{X} \\
\left(\operatorname{Le}^{a}+X\right)\end{array}$ & $\begin{array}{l}24 / 56 \\
9 / 48 \\
33 / 104\end{array}$ & $\begin{array}{l}\mathbf{L} \mathbf{e}^{b} \\
\mathbf{Y} \\
\left(\mathbf{L} \mathbf{e}^{\mathrm{b}}+\mathbf{Y}\right)\end{array}$ & $\begin{array}{c}78 / 21 \\
84 / 50 \\
162 / 71\end{array}$ & $\begin{array}{l}\left(L e^{a}+L e^{b}\right) 102 / 77 \\
(X+Y) \frac{93 / 98}{195 / 175} \\
\text { Total }\end{array}$ \\
\hline $\begin{array}{l}\operatorname{Le}^{a+b-} \\
(n=9)\end{array}$ & $\begin{array}{l}1 \\
2\end{array}$ & $\begin{array}{l}\operatorname{Le}^{a} \\
\mathbf{X} \\
\left(\mathbf{L e}^{a}+\mathbf{X}\right)\end{array}$ & $\begin{array}{l}58 / 41 \\
15 / 32 \\
73 / 73\end{array}$ & $\begin{array}{l}\mathbf{L} e^{b} \\
\mathbf{Y} \\
\left(\mathbf{L} e^{b}+\mathbf{Y}\right)\end{array}$ & $\begin{array}{l}39 / 35 \\
56 / 60 \\
95 / 95\end{array}$ & $\begin{array}{l}\left(L e^{a}+L e^{b}\right) 97 / 76 \\
(X+Y) \frac{71 / 92}{168 / 168} \\
\text { Total }\end{array}$ \\
\hline
\end{tabular}

The score represents the mean of scores recorded for $8 \mathrm{Le}^{\mathrm{a}-\mathrm{b}+}$ and $9 \mathrm{Le}^{\mathrm{a}+\mathrm{b}-}$ patients.

$\mathrm{H}$ gene(s). This is accompanied by enhanced synthesis of the monofucosylated substances $\mathrm{Le}^{\mathrm{a}}$ and $\mathrm{X}$, possibly due to increased substrate availability. Thus despite pronounced quantitative differences for each antigen between neoplastic and normal urothelium, the sum of the scores is barely affected (table 4 ). The phenotypically $\mathrm{Le}^{\mathrm{a}+\mathrm{b}-}$ persons who normally have weak expression of the $\mathrm{Se} / \mathrm{H}$ gene(s) show no further reduction of the difucosylated substances Le ${ }^{b}$ and $Y$ in their TCCs. The differences between normal and neoplastic tissues are limited to a reciprocal change of $\mathrm{Le}^{\mathrm{a}}$ and $\mathrm{X}$. An excess of $\mathrm{X}$ was noted in TCCs from all three phenotypes and suggests either a relatively high activity of the $\mathrm{X}$ enzyme or greater availability of the type 2 substrates. Indeed, there is a reversal of the type 1 : type 2 substance ratio in TCCs compared with normal controls (table 4). Evidence for an excess of type 2 precursors has been also found in colon cancer. ${ }^{9}$ Using enzymatic assays, Orntoft et al found that the fucosyltransferases from either normal urothelium or TCCs showed somewhat higher activity when type 1 acceptors were used. ${ }^{14}$ This apparent discrepancy from our results may be explained by the different reaction conditions and the possibility that differences in substrate accessibility that pertain in vivo are not reproduced in the in vitro assays.

An overexpression of $\mathrm{X}$ has previously been noted in TCCs ${ }^{10}$ and pancreatic carcinomas ${ }^{11}$ while an increase in $\mathrm{Y}$ has been reported for renal cell carcinoma. ${ }^{23}$ Tissue-dependent factors may account for these apparently conflicting results.

The endothelial cells seem to express only the $\mathrm{Y}$ and offer a good example of the tissuedependent variability of the Lewis phenotype. This antigen may be synthesised independently of the Le/Se genes through the action of the $\mathrm{H}$ gene product which utilises type 2 precursor to form H-type 2 chains which are then transformed to $\mathrm{Y}$ by the $\mathrm{X}$ gene product (fig 7). The dependence of the endothelial reactivity for $\mathrm{Y}$ on the $\mathrm{ABO}$ phenotype also reflects the effect of enzyme competition for common substrate.

In conclusion, this study establishes a definite pattern of quantitative differences in the expression of Lewis antigens in normal urothelium which is related, but not identical with the red blood cell phenotype. We suggest that this pattern results primarily from different levels of $\mathrm{Se}$ gene expression and secondarily from competitive substrate utilisa-
(A)

()
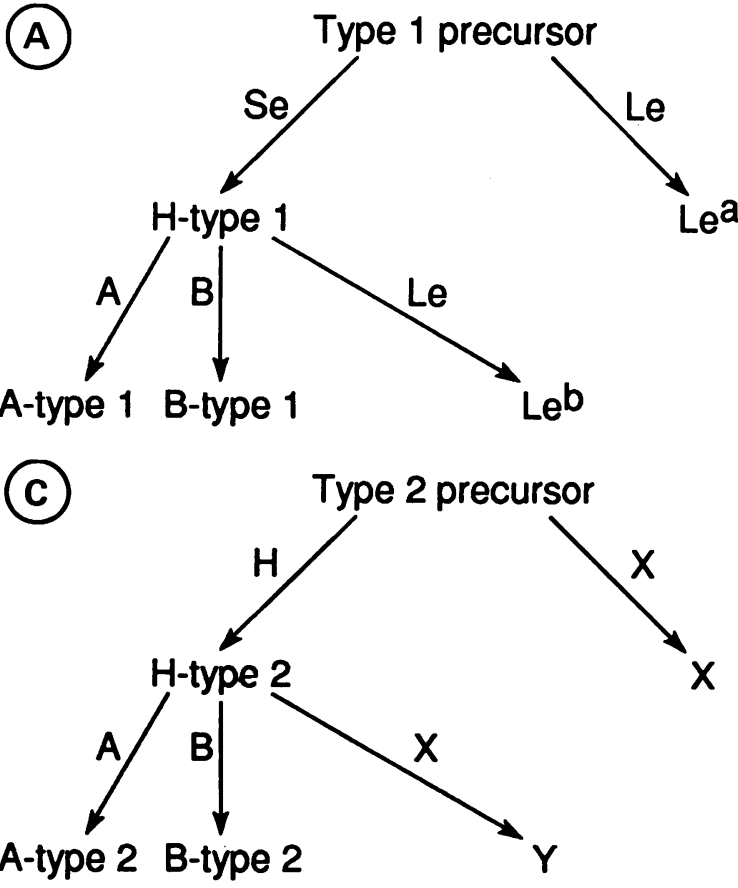

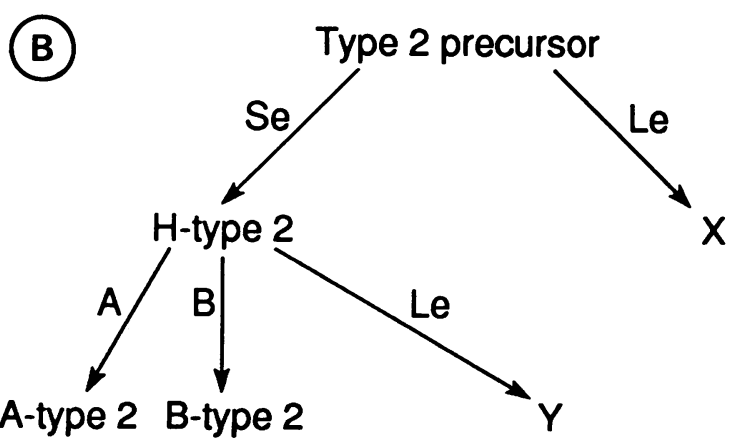

Figure 7 Simplified diagram of the biosynthesis of the $A B O$ and Lewis related antigens. 
tion. In TCCs the antigenic disturbances seem to represent redistribution of determinants generated by a depression of the $\mathrm{Se} / \mathrm{H}$ genes and altered substrate availability.

I thank Drs Paul Lange and Pratap Reddy of the Department of Urological Surgery for contributing clinical material, Dr Bruce Cutler for technical assistance, and Ms LM Starks for typing the manuscript.

Supported in part by a grant [CA 33239] from the National Cancer Institute, National Institutes of Health, Bethesda, MD.

1 Decenzo JM, Howard P, Irish E. Antigenic deletion and prognosis of patients with stage A transitional cell carcinprognosis of patients with st.

2 Limas C, Lange P, Fraley EE, et al. ABH antigens in transitional cell tumors of the urinary bladder. Correlation with the clinical course. Cancer 1979;44:2099-107.

3 Richie JP, Blute RD, Waisman J. Immunologic indicators of prognosis in bladder cancer: The importance of cell surface antigens. J Urol 1980;123:22-4.

4 Thorpe SJ, Abel P, Henderson D, et al. Expression of blood group antigens in urinary tract tumours: Prospective fluorescence study using cryostat sections of fresh frozen tissues. J Clin Pathol 1986;39:1165-76.

5 Watkins WM. Biochemistry and genetics of the ABO, Lewis and P blood group systems. Adv Hum Genet 1980;10: and $P$ blood

6 Oriol R, LePendu J, Mollicone R. Genetics of ABO, H, Lewis $\mathrm{X}$ and related antigens. Vox Sang 1986;51:161-71.

7 Limas C, Lange PH. Lewis antigens in normal and neoplastic urothelium. Am J Pathol 1985;121:176-83.

$8 \mathrm{Juhl}$ BR, Harlzen SH, Hainau B. Lewis a antigen in transitional cell tumors of the urinary bladder. Cancer 1986;58:222-8.

9 Holmes EH, Ostrander GK, Clausen H, et al. Oncofetal expression of $\mathrm{Le}^{\mathrm{x}}$ carbohydrate antigens in human colonic adenocarcinomas. J Biol Chem 1987;262:11331-8.

10 Cordon-Cardo C, Reuter VE, Lloyd FO, et al. Blood group- related antigens in human utothelium. Enhanced expression of precursor, $\mathrm{Le}^{x}$ and $\mathrm{Le}^{y}$ determinants in urothelial carcinoma. Cancer Res 1988;48:4113-20.

11 Kim YS, Itzkowitz SH, Yuan M, et al. Le and $^{x} \mathrm{Le}^{y}$ antigen expression in pancreatic cancer. Cancer Res 1988;48: 475-82.

12 Limas C. Detection of urothelial Lewis antigens with monoclonal antibodies. Am J Pathol 1986;125:515-23.

13 Orntoft TF, Wolf H, Clausen $\mathrm{H}$, et al. Blood group ABO and Lewis antigens in fetal and normal adult bladder urothelium: Immunohistochemical study of type 1 chain thelium: Immunohistochemical stud

14 Orntoft TF, Wolf $H$, Watkins WM. Activity of the human blood group ABO, Se, H, Le and $X$ gene-encoded glycosyltransferases in normal and malignant bladder urothelium. Cancer Res 1988;48:4427-33.

15 Lloyd KO, Larson G, Stromber N, et al. Mouse monoclonal antibody F-3 recognizes the difucosyl type 2 blood group structures. Immunogen 1983;17:537-41.

16 Sakamoto J, Yin BWT, Lloyd KO. Analysis of the expression of $H$, Lewis $X, Y$ and precursor blood group determinants in saliva and red cells using a panel of mouse monoclonal antibodies. Mol Immunol 1984;21:1093-8.

17 Sakamoto J, Furukawa K, Cordon-Cardo C, et al. Expression of Lewis A, Lewis $\mathrm{B}, \mathrm{X}$ and $\mathrm{Y}$ blood group antigens in human colonic tumors, normal tissue and in human tumor human colonic tumors, normal tissue and in human

18 Cordon-Cardo C, Lloyd KO, Finstad CL, et al. ImmunoCordon-Cardo C, Lloyd KO, Finstad CL, et al. Immuno-
antomic distribution of blood group antigens in the human urinary tract and influence of secretor status. Lab Invest 1986;55:444-54.

19 Mollicone R, Bara J, LePendu J, Oriol R. Immunohistologic pattern of type 1 (Le", Le ${ }^{b}$ ) and type $2(X, Y, H)$ blood group-related antigens in the human pyloric and duodenal mucosae. Lab Invest 1985;53:219-22.

20 Marcus DM, Cass LE. Glycosphinogolipids with Lewis blood group activity uptake by human erythrocytes. Science 1989;164:553-5.

21 Lewis M, Kaita H, Chown B. The blood groups of a Japanese population. Am J Hum Genet 1957;9:274-83.

22 Sakamoto S, Watanabe T, Tokumaru T, et al. Expression of Lewis", Lewis ${ }^{\mathrm{b}}$, Lewis ${ }^{x}$, Lewis', sialyl-Lewis' and sialylLewis ${ }^{b}$ blood group antigens in human gastric carcinoma and in normal gastric tissue. Cancer Res 1989;49:745-52.

23 Cordon-Cardo C, Reuter VE, Finstad CL, et al. Blood group-related antigens in human kidney. Modulation of Lewis determinants in renal cell carcinoma. Cancer Res 1989;49:212-18. 